\title{
Evaluating Performance of Ridge Gourd (Luffa acutangula Roxb.) Cultivation in Pandal System in Nalgonda District of Telangana, India
}

\author{
Murali Bellamkonda $^{1^{*}}$, K. Shailaja ${ }^{1}$ and V. Ravinder Naik ${ }^{2}$ \\ ${ }^{1}$ AICRP on Forage Crops \& Utilization Agricultural Research Institute, Rajendranagar, India \\ ${ }^{2}$ Department of Agricultural Extension, College of Agriculture, Rajendranagar, \\ Jayashankar Telangana State Agricultural University Hyderabad, India \\ *Corresponding author
}

\section{A B S T R A C T}

\section{Keywords \\ Creeping vegetables, cucurbits, gourds, ridge gourd, pandal system and net returns}

\section{Article Info}

Accepted:

12 February 2020 Available Online: 10 March 2020
Ridge gourd is an important cucurbitaceous vegetable, which is an annual herbaceous plant with creeping and climbing habit. Most of the farmers' traditionally cultivating ridge gourd on soil surface with surface irrigation. Farmers are getting not only less yields but also inferior quality fruits with this method of cultivation. This may be due to incidence of more soil borne pests and diseases and unsuitable growing condition to both vine and fruits when compared to trellis or pandal system of cultivation. Previous studies indicated that more yields were produced in trellis and pandal system of cultivation. To evaluate pandal system of ridge gourd cultivation in Nalgonda district of Telangana State, an On-Farm Trial was conducted in three locations during kharif 2016 and repeated in 2017kharif season. In pandal system of cultivation the two year (2016 $\& 2017$ ) average fruit yields obtained by the three farmers ranged from 18450 to $18775 \mathrm{~kg} / \mathrm{Ha}$ and in farmers practice method it was ranged from 8850 to 9225 $\mathrm{kg} / \mathrm{Ha}$. The two year average fruit yields of on-farm trial have shown doubled production over farmers practice method. The three farmers' two years average net returns obtained were Rs.229, 332/-and Rs. 61,537/- in on-farm trial and in farmers practice method respectively.

\section{Introduction}

Ridge gourd or ribbed gourd (Luffa acutangula Roxb.) is known as Luffa gourd or Angled Luffa in most parts of the world. Ridge gourd is one of important cucurbitaceous vegetable crops in India and it is also popular in Southeast Asia and China.
Ridge gourd is cultivating in 24,500 acres approximately in India with production of 316925 Tones (farmnest.com). Ridge gourd is delicious vegetable and its tender fruits can be cooked to prepare various curries and it is also used in making chutneys in South India. Ridge gourd fruits become more fibrous if fruit pickings are delayed and become unfit 
for culinary purposes. Ridge gourd is rich in dietary fibre and enriched with all the vital elements that include Vitamin-C, zinc, iron, riboflavin, magnesium, thiamine and traces of other minerals. It is low in saturated fat, cholesterol and calories that aids in weight loss. Ridge gourd contains good amount of cellulose and high in water content that helps to relieve from constipation.

There is a lot of variation in shape and length of the fruit. Ridge gourd is an annual herbaceous plant grown for about 3 - 4months after sowing. Hence kharif sown crop will not exist for following summer season. For getting good yields sowings should be taken up in June or July for kharif season crop and January or February for summer crop.

Cucurbitaceous vegetables including ridge gourd possesses creeping habit and they also have climbing and trailing habit. Many farmers in India traditionally cultivate cucurbit vegetables on soil surface as a creeping vegetable with surface irrigation. This practice more attracts many plant diseases such as Phytophthera blight, collar rot, bacterial wilt, gummosis, downy mildew, anthracnose etc. when compared to growing these creeper vegetables on aerial trailing systems such as staking, trellis, bower or pandal system.

Pandey et al., 2002 reported that gummosis, anthracnose, Phytophthora blight, Cercospora leaf spot, root knotnematode and watermelon bud necrosis virus are becoming the most destructive diseases among many other diseases occur in cucurbits.

Konsler and Strider (1973) observed that vertical trailing or staking found to be superior in increasing yield and obtaining good fruit quality and better control of foliar and fruit diseases in cucumber over growing it on ground cultivation. Sadanandan (2013) had reported that highest fruit yields were obtained in horizontal trailing system than vertical trailing system of cucumber grown in rain shelter in Vellanikkara Kerala.Growing of pickling cucumber on wires has given not only higher fruit yields but also good quality when compared to growing them on the ground (Tokatly and Ozgur, 1999).

Some farmers are obtaining higher yields by cultivating cucurbit vegetables by adopting drip irrigation system along with plastic mulching over surface irrigation method. This may be due to less weed infestation and hence low pests and disease incidence. Growing creeper vegetables like bitter gourd, bottle gourd, and ridge gourd on pandals is a technological improvement for getting not only higher yield, but also better quality.

Pandal grown cucurbits produce uniform sized fruits with uniform skin colour which attract better price in the market. Peter et al., (2008) reported that cucurbit vegetables such as bitter gourd, snake gourd, ridge gourd, and ivy gourd grown on pandal system produced higher yields and better fruit quality in Kerala. Balaji et al., (2016) in their study reported that ribbed gourd cultivated on pandal system in 3 villages each of Anaimalai block and Madukkarai block has given an average yield of 17.50 tonnes with net returns of Rs.145285 per hectare which was technologically improved practice over traditional method of ribbed gourd cultivation in Tamilnadu.

Training is an important practice for vegetables for obtaining optimum vegetative growth, higher yield and good quality produce (Narayan et al., 2008).Keeping this in view we have conducted an On-Farm Trial in Nalgonda District of Telangana State in India in three locations during kharif 2016 and repeated in kharif2017. 


\section{Materials and Methods}

\section{Farmer practice}

\section{Field preparation \& sowing}

Nalgonda farmers of Telangana traditionally growing ridge gourd on soil surface with surface irrigation. In farmers practice field was ploughed with tractor drawn mould board plough once and with cultivator twice followed by a rotavator to get fine tilth. Later furrows were formed, with country plough consisting of a blade, at spacing of $2.5 \mathrm{~m}$. Ridge gourd hybrid Ajeet-Bonanja was sown at $2.0 \mathrm{~m}$ spacing within the furrow with two seeds per pit of $30 \mathrm{~cm} \times 30 \mathrm{~cm} \times 30 \mathrm{~cm}$ sizes. 750 grams seed per acre was used and sowings were taken up by farmers in 3 locations in the second fortnight of June in year 2016 and first fortnight of Julyin year 2017.

\section{Manures and fertilizers}

Farm Yard Manure @ four tractor loads per acre was applied to the field during field preparation. Total of 69,24 and $45 \mathrm{~kg}$ of Nitrogen, Phosphorus and Potash was applied per acre respectively. Phosphorous fertilizer in the form of single super phosphate (SSP) of three $50 \mathrm{~kg}$ bags of was applied as basal and nitrogen and potash were applied in three split applications per acre in the form of urea and muriate of potash (MOP). First split was applied at ten days after sowing, second split was applied at 25 days after first split application and third split was applied also at 25 days after second split application near to plant in the row.

\section{Irrigation}

First irrigation was given before sowing to fill the pits through furrow-channel and subsequent irrigations were given at weekly intervals except that if rainfall occurs sufficiently.

\section{Weeding}

Intercultural operations were taken up with bullock drawn gorru two times at 15 and 30 days after sowing coupled with manual weeding around the plant base.

\section{Pest and disease control}

Beetles and aphids were infested during early stage of crop growth and fruit fly infestation was occurred beginning 75 days after sowing. Acephate was sprayed for control of beetles and aphids and for control of fruit fly incidence triazophos was sprayed but found to be not effective. Hence poison baits were installed@201/acre (jaggery 50g/litre of water + abamectin 1.9\% EC $0.0025 \%$ )above ground level here and there within the field. Farmers sprayed mancozeb @ 2gm/l of water for control of gummy stem blight and also for anthracnose leaf spot. Downy mildew and powdery mildew diseases were observed during flowring and fruiting time and these were managed by spraying chlorothalonil @ 2gm/l and dinocap @ 1ml/l of water.

\section{Harvesting}

Fruits are attached to plant vines spread on soil surface and sometimes dirt or mud may adhere to matured fruits while picking. These matured fruits were cleaned with water before packing to gunny bags or empty fertilizer polythene bags.

\section{Pandal system}

Telangana State government through Department of Horticulture is encouraging vegetable farmers to take up permanent pandal system for growing creeping vegetables more profitably on subsidy. Hence 
many Nalgonda district vegetable farmers have taken up permanent pandal system to utilize government subsidy facility.

As per guidelines of RKVY 2014-15 India, the Department of Horticulture - Government of Telangana was providing the guidelines for erection of permanent pandals per acre in the following table which includes total cost estimation including labour and subsidy component:

\section{Field preparation \& sowing}

Under pandal system of cultivation, Nalgonda farmers of Telangana started cultivating ridge gourd on surface of G-wire nets of pandals with drip irrigation along with plastic mulching. Field was ploughed with tractordrawn mould board plough one time and tractor with cultivator ploughed twice and one time with rotavatorto get fine tilth. Later bunds were formed with tractor drawn bund former at spacing of $2.0 \mathrm{~m}$ between two adjacent bunds. Ridge gourd hybrid AjeetBonanja was sown at two feet spacing on center of the bund covered with plastic much sheet and holes were made to facilitate sowing of seed.

In the same fashion sowings were taken up by farmers in 3 locations in the second fortnight of June in year 2016 and first fortnight of July in year 2017. Fertilizers:Total of 100-40-40 $\mathrm{kg}$ per acre of N-P-K was applied per acre respectively through drip irrigation system. $75 \%$ of RD of phosphorous (40 kg/acre) was applied in the form of Single Super Phosphate as basal and remaining phosphorous, nitrogen and potash fertilizers were applied through drip fertigation system as per the schedule given in the following table.

The same fertigation schedule was provided to follow by the three farmers located in the three different villages in Nalgonda district.

\section{Drip irrigation}

Drip system was established with main and sub-main pipe and inline lateral tubes were placed at an interval of $2.0 \mathrm{~m}$. Within the each lateral tube drippers were provided at an interval of $60 \mathrm{~cm}$ with 4 Litres Per Hour and $50 \mathrm{~cm}$ spacing with 3.5 Litres Per Hour capacities.

\section{Weeding}

Plastic mulching along with drip irrigation was provided in the pandal sytem and hence bunds area were weed free. Intercultural operations were done with mini tractor under pandals to remove weeds grown in the area between two bunds.

\section{Pest and disease control}

Aphids were infested during early stage of crop growth and fruit fly infested the vines two months after sowing. Acephate was sprayed for control of aphids and for control of fruit fly incidence triazophos was sprayed but found to be not effective. Hence poison baits were installed @ 20 1/ha (jaggery $50 \mathrm{~g} / \mathrm{litre}$ of water + abamectin $1.9 \% \mathrm{EC}$ $0.0025 \%$ ) below to the pandals here and there within the field. Anthracnose leaf spot, downy mildew and powdery mildew diseases were observed during crop growth.

Anthracnose was controlled by spraying propiconazole@1ml/l of water and downy mildew disease was managed by spraying mancozeb @ 2gm/l of water and one week later with spraying chlorotholonil @ 2 gm/l of water and powdery mildew incidence was occurred during onset of winter months after sowing (October onwards)and controlled by spraying carbendizm @ $1 \mathrm{gm} / \mathrm{l}$ of water followed by dinocap @ 1ml/l of water 10 days after spraying of carbendizm fungicide. 


\section{Harvesting}

Picking of green fruits was done into bamboo baskets to reduce fruit bruise or damage. Then packed them into carton boxes by keeping some paper materials underneath of the boxes to keep freshness of fruits for longer time and supply to Spencer's and Reliance stores.

\section{Kharif 2016 Results}

In 2016 khrif season among the three farmers who have taken up the on-farm trial, the farmer Sri BarishettiBala Raju produced highest fruit yield, 9400 kgper hectare in farmer practice method and farmer Sri Konatham Sathi Reddy has produced highest fruit yield $(18400 \mathrm{~kg}$ per hectare) in treatment, the pandal system with drip irrigation. However the three farmers produced higher yield which ranges from $88 \%$ to $116 \%$ over farmer practice i.e. growing on soil surface with furrow irrigation method. The details of experimental results are provided in the following table. The average net returns of three farmers obtained in kharif 2016 was Rs. 200,000/- in on-farm trial and Rs. 58,000/- in farmers practice method. Benefit cost ratio of farmers practice was 2.81:1 and BC ratio of OFT was 3.85:1.

\section{Kharif 2017 results}

In 2017 khrif season among the three farmers, the farmer Sri MandadiNarsi Reddy of Dandempally Nalgonda District have produced highest fruit yield, $9350 \mathrm{~kg}$ and $19650 \mathrm{~kg}$ per hectare in farmer practice method and On-Farm Trial. However the three farmers produced higher yield which ranges from $104 \%$ to $115 \%$ over farmer practice method. The experimental details results are given in the following table.In kharif 2017, the average net returns of 3 farmers was Rs. 74,300/- whereas on-farm trial's average net returns was Rs. 260,000/-. $\mathrm{BC}$ ratio of farmers' practice and on-farm trial was 2.83:1 and 4.05:1 respectively.

Table.1 Details of permanent pandal system establishment costs adopted by Telangana State Government

\begin{tabular}{|l|l|l|l|l|l|}
\hline S. No. & Particulars & Unit & Qty & Rate & $\begin{array}{l}\text { Amount } \\
\text { (Rs.) }\end{array}$ \\
\hline $\mathbf{1}$ & $\begin{array}{l}\text { Erection of Stone/CC Pillars of 10' } \\
\text { Height @ 15'x18' Spacing } \\
\text { (including support pillars) }\end{array}$ & Nos. & 185 & 350 & 64,750 \\
\hline $\mathbf{2}$ & $\begin{array}{l}\text { Steel wire for framework \& internal } \\
\text { network. (8gauge \& 10gauge) }\end{array}$ & Qtl. & 15 & 7500 & $1,12,500$ \\
\hline $\mathbf{3}$ & $\begin{array}{l}\text { Labour Charges (For Digging of } \\
\text { Pits, } \\
\text { Fixing of pillars, Stretching of wire } \\
\text { etc.,) }\end{array}$ & Nos. & LS & & 40,000 \\
\hline $\begin{array}{l}\text { Total } \\
\text { Part of the cost is borne by farmer \& the unit (acre) cost is restricted to Rs. 2,00,000/- }\end{array}$ \\
\hline 50\% subsidy on unit cost = Rs. 1,00,000/- \\
\hline $\begin{array}{l}\text { Maximum subsidy eligibility limit is to an extent of 1.00 ha with a subsidy limit to Rs. } \\
\text { 2.5 lakhs per hectare }\end{array}$
\end{tabular}


Table.2 Fertigation schedule in ridge gourd (hybrid) followed as per the recommendation of TNAU Crop Production Techniques of Horticultural Crops 2013 publication

\begin{tabular}{|c|c|c|c|c|c|}
\hline S.No. & Crop Stage & $\begin{array}{l}\text { Duration } \\
\text { in Days }\end{array}$ & $\begin{array}{l}\text { Fertilizer } \\
\text { Grade }\end{array}$ & $\begin{array}{l}\text { Total } \\
\text { Fertilizer } \\
\text { (kg/acre) }\end{array}$ & $\begin{array}{c}\% \\
\text { requirement } \\
\text { N-P-K }\end{array}$ \\
\hline 1 & $\begin{array}{l}\text { Crop } \\
\text { Establishment } \\
\text { stage }\end{array}$ & 10 & $\begin{array}{l}12-61-0 \\
13-0-45 \\
\text { Urea }\end{array}$ & $\begin{array}{c}13.11 \\
8.80 \\
15.80\end{array}$ & $10-5-10$ \\
\hline 2 & $\begin{array}{l}\text { Vegetative } \\
\text { stage }\end{array}$ & 30 & $\begin{array}{l}19-19-19+ \\
\text { MN } \\
\text { Urea }\end{array}$ & $\begin{array}{l}---- \\
63.15 \\
39.06\end{array}$ & $30-7.5-30$ \\
\hline 3 & $\begin{array}{l}\text { Flower } \\
\text { initiation } \\
\text { stage to first } \\
\text { picking stage }\end{array}$ & 20 & $\begin{array}{l}12-61-0 \\
13-0-45 \\
\text { Urea }\end{array}$ & $\begin{array}{l}19.66 \\
17.60 \\
55.00\end{array}$ & $30-7.5-20$ \\
\hline 4 & $\begin{array}{l}\text { Harvesting } \\
\text { stage }\end{array}$ & 60 & $\begin{array}{l}12-61-0 \\
13-0-45 \\
\text { Urea }\end{array}$ & $\begin{array}{l}13.11 \\
35.20 \\
51.75\end{array}$ & $30-5-40$ \\
\hline 5 & $\begin{array}{l}\text { Total } \\
\text { duration }\end{array}$ & 120 & Total & $\begin{array}{c}\text { N100,P10*\&K } \\
40 \mathrm{~kg} / \text { acre }\end{array}$ & $100-25-100$ \\
\hline
\end{tabular}

Table.3 Yield and economics of ridge gourd cultivation in farmers practice and permanent pandal system

\begin{tabular}{|r|l|l|c|c|}
\hline S.No. & Name of the farmer & Village \& Mandal & $\begin{array}{c}\text { Farmer } \\
\text { Practice Yield } \\
\text { (kg/Ha) }\end{array}$ & $\begin{array}{c}\text { Trial } \\
\text { Yield (kg/Ha) }\end{array}$ \\
\hline $\mathbf{1}$ & Barishetti Bala Raju & Marrur, Nakirekal & 9400 & 17700 \\
\hline $\mathbf{2}$ & $\begin{array}{l}\text { KonathamSathi } \\
\text { Reddy }\end{array}$ & Chityal & 8500 & 18400 \\
\hline $\mathbf{3}$ & $\begin{array}{l}\text { MandadiNarsi } \\
\text { Reddy }\end{array}$ & $\begin{array}{l}\text { Dandempally, } \\
\text { Nalgonda }\end{array}$ & 9100 & 17900 \\
\hline & & $\begin{array}{l}\text { Average yield of } \\
\text { three farmers }\end{array}$ & 9000 & 18000 \\
\hline & & \multicolumn{2}{|c|}{ Economics of three farmers' average } \\
\hline & & Cost of Cultivation & 32000 & 70000 \\
\hline & & Gross Returns & 90000 & 270000 \\
\hline & & Net Returns & 58000 & 200000 \\
\hline & & & $2.81: 1$ & $3.85: 1$ \\
\hline & & & $\begin{array}{l}\text { Average Price } \\
\text { Rs } 10000 / \text { MT }\end{array}$ & $\begin{array}{l}\text { Average Price } \\
\text { Rs. 15000/MT }\end{array}$ \\
\hline
\end{tabular}


Table.4 Yield and economics of ridge gourd cultivation in farmers practice and permanent pandal system

\begin{tabular}{|r|l|l|c|c|}
\hline $\begin{array}{l}\text { S. } \\
\text { No. }\end{array}$ & Name of the farmer & Village \& Mandal & \multicolumn{1}{|c|}{$\begin{array}{l}\text { Farmer practice } \\
\text { Yield (kg/Ha) }\end{array}$} & $\begin{array}{l}\text { Trial yield } \\
\text { (kg/Ha) }\end{array}$ \\
\hline $\mathbf{1}$ & BarishettiBala Raju & Marrur, Nakirekal & 8900 & 19200 \\
\hline $\mathbf{2}$ & KonathamSathi Reddy & Chityal & 9200 & 18800 \\
\hline $\mathbf{3}$ & MandadiNarsireddy & $\begin{array}{l}\text { Dandempally, } \\
\text { Nalgonda }\end{array}$ & 9350 & 19650 \\
\hline & & $\begin{array}{l}\text { Average yield of } \\
\text { three farmers }\end{array}$ & 9150 & 19216 \\
\hline & & \multicolumn{1}{|c|}{ Economics of three farmers' average } \\
\hline & & Cost of Cultivation & 35500 & 85400 \\
\hline & & Gross Returns & 100650 & 345888 \\
\hline & & Net Returns & 74300 & 260488 \\
\hline & & B C Ratio & $2.83: 1$ & $4.05: 1$ \\
\hline & & & $\begin{array}{l}\text { Average Price } \\
\text { Rs.11000/ MT }\end{array}$ & $\begin{array}{l}\text { Average Price } \\
\text { Rs. 18000/MT }\end{array}$ \\
\hline
\end{tabular}

Table.5 Yield and economics of ridge gourd cultivation in farmers' practice and permanent pandal system (average of 2016 and 2017)

\begin{tabular}{|r|l|l|c|c|}
\hline S.No. & Name of the farmer & \multicolumn{1}{|c|}{$\begin{array}{c}\text { Village \& } \\
\text { Mandal }\end{array}$} & $\begin{array}{c}\text { Farmer } \\
\text { Practice Yield } \\
\text { (kg/ha) }\end{array}$ & $\begin{array}{c}\text { OFT Yield } \\
\text { (kg/ha) }\end{array}$ \\
\hline $\mathbf{1}$ & BarishettiBala Raju & $\begin{array}{l}\text { Marrur, } \\
\text { Nakirekal }\end{array}$ & 9150 & 18450 \\
\hline $\mathbf{2}$ & Konatham Sathi Reddy & Chityal & 8850 & 18600 \\
\hline $\mathbf{3}$ & MandadiNarsi Reddy & $\begin{array}{l}\text { Dandempally, } \\
\text { Nalgonda }\end{array}$ & 9225 & 18775 \\
\hline & & $\begin{array}{l}\text { Average yield of } \\
\text { three farmers }\end{array}$ & 9075 & 18608 \\
\hline & & \multicolumn{1}{|c|}{ Economics of three farmers' average } \\
\hline & & $\begin{array}{l}\text { Cost of } \\
\text { Cultivation }\end{array}$ & 33750 & 77700 \\
\hline & & Gross Returns & 95287 & 307032 \\
\hline & & Net Returns & 61537 & 229332 \\
\hline & & B C Ratio & $2.82: 1$ & $3.95: 1$ \\
\hline & & & $\begin{array}{l}\text { Average Price } \\
\text { Rs.10500/ MT }\end{array}$ & $\begin{array}{l}\text { Average Price } \\
\text { Rs. 16500/MT }\end{array}$ \\
\hline
\end{tabular}


Table.6 The mean of 2016 \& 2017 year cost of cultivation operation wise in

Farmers Practice and in On-Farm Trial

\begin{tabular}{|c|c|c|c|c|c|}
\hline $\begin{array}{l}\text { S. } \\
\text { No. }\end{array}$ & Particulars/ operations & $\begin{array}{l}\text { Farmers } \\
\text { Practice }\end{array}$ & $\begin{array}{l}\text { Amount } \\
\text { in Rs. Per } \\
\text { Ha }\end{array}$ & On-Farm Trial & $\begin{array}{l}\text { Amount in } \\
\text { Rs. Per } \\
\text { Ha }\end{array}$ \\
\hline 1 & $\begin{array}{l}\text { Ploughing with Tractor } \\
\text { operated MB plough }\end{array}$ & Once & 3500 & Once & 3500 \\
\hline 2 & Cultivator & Twice & 3000 & Twice & 3000 \\
\hline 3 & Farm Yard Manure & Nil & 0 & $15 \mathrm{MT}$ & 45000 \\
\hline 4 & Rotavator & Once & 2500 & Once & 2500 \\
\hline 5 & $\begin{array}{l}\text { Tractor drawn Bund } \\
\text { Former }\end{array}$ & Nil & 0 & Once & 1200 \\
\hline 6 & $\begin{array}{l}\text { Formation of furrows } \\
\text { with country plough } \\
\text { with blade }\end{array}$ & Once & 1500 & NA & 0 \\
\hline 7 & Sowing & 5 women & 2000 & 5 women & 2000 \\
\hline 8 & Weeding & 39 women & 7800 & 16 women & 3200 \\
\hline 9 & Irrigations & 8 man days & 2000 & $\begin{array}{l}\text { drip system } 3 \text { man } \\
\text { days }\end{array}$ & 750 \\
\hline 10 & Plant protection & 4 sprayings & 4650 & 3 sprayings & 3550 \\
\hline 11 & Fruit harvesting & 34 women & 6800 & 65 women & 13000 \\
\hline 12 & Total in Rupees & & 33750 & & 77700 \\
\hline
\end{tabular}

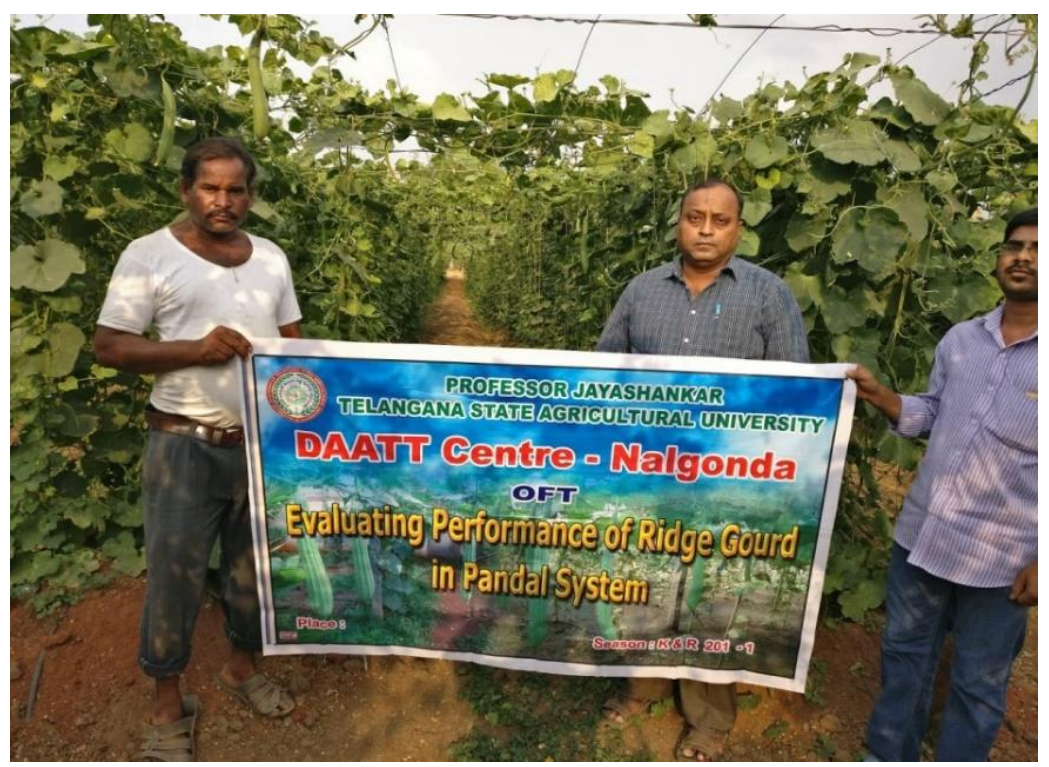

Figure.1 On Farm Trial (OFT) on evaluating performance of ridge gourd in pandal system was conducted in the field of Sri KonathamSathi Reddy in Chityal village and Mandal, Nalgonda district in kharif 2016 \& 2017 


\section{Average of two year (2016 \&2017) kharif season results}

Two years average results of three farmers were given in the table 5. The two year average fruit yield of three farmers varied from $8850 \mathrm{~kg} / \mathrm{Ha}$ to $9225 \mathrm{~kg} / \mathrm{Ha}$ and 18450 $\mathrm{kg} / \mathrm{Ha}$ to $18775 \mathrm{~kg} / \mathrm{Ha}$ in farmers' practice and on-farm trial respectively. Therefore the two year average fruit yields of the 3 farmers of Nalgonda district in the trial had produced $101 \%$ to $110 \%$ higher yield over farmers' practice method. The three farmers have got the average net returns of Rs. 229, 332 in onfarm trial and Rs. 61,537/- in farmers practice method this is calculated by making average of the two year results. Balaji et al., 2016 had also reported the similar results in a study taken up in three blocks and 3 villages in each block in Tamil Nadu. Two year average of $\mathrm{BC}$ ratios was 2.82:1 and 3.95:1 in farmer's practice and on-farm trial respectively. That means for every rupee invested in the pandal system ridge gourd cultivation, Nalgonda farmers got 3.95 rupees. This may be due to congenial growing condition to both vine and also fruits.

Ridge gourd is one of the important cucurbitaceous vegetable crops in India. Which is an annual herbaceous plant with creeping and climbing habit this is giving opportunities to explore new crop cultivation techniques. However, farmers' traditionally cultivating ridge gourd on soil surface with surface irrigation. Because of this farmers are getting not only less yields but also inferior quality fruits due to soil borne pest and disease incidence and unfavourable growing condition to both vine and fruits when compared to trellis or pandal system of cultivation. To evaluate pandal system of ridge gourd cultivation in Nalgonda district of Telangana State, an On-Farm Trial was conducted in three locations during kharif 2016 and kharif 2017. In pandal system of cultivation the highest two year average yield obtained was $18775 \mathrm{~kg} / \mathrm{Ha}$ and in farmers practice method it was $9225 \mathrm{~kg} / \mathrm{Ha}$. That indicates simply doubled production over farmers practice method. It was observed that average fruit price was Rs. 16,500/- with pandal system of cultivation which might be due to good fruit quality and uniform long fruits. In pandal system of cultivation farmers received higher gross returns Rs. 307032/and net returns and BC ratio of Rs. 229332/and 3.95:1 respectively. Whereas in farmers practice average price obtained was Rs. 10,500/- and net returns and BC ratio obtained were Rs. 61537/- and 2.82:1 respectively.

\section{References}

Balaji, P., Kumaresan, S., and Sivakumar, S.D. 2016. Economic analysis of pandal (structure for creeper crops) vegetables cultivation in Coimbatore district of Tamil Nadu. Internat. Res. J. Agric. Eco. \& Stat., 7 (1): 56-62

Crop Production Techniques of Horticultural Crops 2013 published by Horticultural College \& Research Institute Tamil Nadu Agricultural Institute Coimbatore 641003 (http://agritech.tnau.ac.in/pdf/2013/cp g_horti_2013.pdf)

Konsler, T.R. and Strider, D.L. 1973. The response of cucumber to trellis and ground culture. Hort. Sci. 8(3):220221

Narayan, S., Ahmed, N., Bhat, S.A., Khan, S.H., and Chatto, M.A. 2008. Improvement in production technology for increasing yield of vegetables. Indian Fmr's Digest 41(2): 33-39

Pandey, K.K., Pandey, P.K., and Satpathy, S. (2002). Integrated management of diseases and insects of tomato, chilli and cole crops Tech. Bull. No. 9. 
Indian Institute of Vegetable Research, Varanasi, p. 1-22.

Peter, K.V., Kumar, P.G.S., and Devi, S.N. 2008. Vegetable crops research initiatives. In. Chadha, K.L., Singh, A.K., and Patel, V.B. (eds). Recent initiatives in Horticulture. The Hort. Sci. of India, New Delhi. Pp 55-63.

Ridge gourd cultivation guide published by farmnest.com

(https://discuss.farmnest.com/t/ridgegourd-cultivation-guide/22189)

RKVY 2014-15Guidelines - Department of Horticulture Government of
Telangana India

Sadanandan, A. 2013. Productivity of cucumber (Cucumis sativus L.) as influenced by seasons and growing systems - M.Sc. (Horticulture) thesis submitted to Department of Olericulture, College of Horticulture Vellanikkara Kerala Agricultural University Thrissur

Tokatly, N. and Ozgur, M. 1999. The effects of vertical training onwires on yield and quality in growing of pickling cucumber. Acta. Hort. 491:121-125.

\section{How to cite this article:}

Murali Bellamkonda, K. Shailaja and Ravinder Naik. V. 2020. Evaluating Performance of Ridge Gourd (Luffa acutangula Roxb.) Cultivation in Pandal System in Nalgonda District of Telangana, India. Int.J.Curr.Microbiol.App.Sci. 9(03): 1489-1498.

doi: https://doi.org/10.20546/ijcmas.2020.903.174 